\title{
EFFECTS OF MORINGA OLEIFERA ON THE DEVELOPING CEREBRUM OF YOUNG WISTAR RATS
}

\author{
Abijo A Z ${ }^{1}$, Adeeyo $00^{2}$, Komolafe $0 A^{1}$, Saka $0 S^{1}$, Abodunrin $V K^{1}$ \\ ${ }^{1}$ Department of Anatomy and Cell Biology, Faculty of Basic Medical Sciences, Obafemi Awolowo \\ University (OAU), Ile Ife, Osun-State, Nigeria. \\ ${ }^{2}$ Department of Human Anatomy, Faculty of Basic Medical Sciences, Ladoke Akintola University of \\ Technology, Ogbomoso, Oyo-State, Nigeria \\ *Correspondence to Abijo Ayodeji Z. Correspondence address: Department of Anatomy and Cell \\ Biology, OAU. Email address: abijoayodeji@gmail.com ; Tel: +2347068789347
}

\begin{abstract}
The study evaluated the effects of moringa oleifeira on the histoarchitecture of the cerebral cortex, the body weight and brain weight of young wistar rats. Fifteen (15) young wistar rats of both sexes weighing $20-30 \mathrm{~g}$ were used for this study. They were randomly assigned into three groups $(A, B$ and $C)$ of five rats each. Group A served as control and received distilled water, group B and C received 100 $\mathrm{mg} / \mathrm{kg}$ and $200 \mathrm{mg} / \mathrm{kg}$ of moringa oleifera respectively. Treatment lasted for a period of 6 weeks (orally). Rats were weighed and sacrificed under ketamine $(30 \mathrm{mg} / \mathrm{kg}$ ) anaesthesia. The cerebrum was harvested and fixed immediately in $10 \%$ formolcalcium, for further histological processing. One-way ANOVA was used to analyze data, followed by Newan-Keuls (SNK) for multiple comparisons. The results showed that there was significant increase in the feed intake of animals in groups $B$ and $C$ starting from the 4th week of administration. There was no significant difference in the relative brain weight and the mean weight of the rats in group B and C when compared with group A. Histological findings revealed that there was slight distortion in group $B$ and more distortion in group $C$ when compared with the normal histoarchitecture in control group A. The results obtained from this study showed that high doses of Moringa oleifera caused damage of some parts of histoarchitecture of the frontal cortex of developing wistar

Key words: MORINGA OLEIFERA; Cerebrum; Frontal Cortex
\end{abstract}

\section{INTRODUCTION}

In the last few decades, there has been an increased growth in the field of herbal medicine and these drugs are gaining popularity both in developing and developed countries because of their natural origin and minimal side effects (Grover et al., 2002; Keter and mutiso, 2011). Many traditional medicines in use are derived from medicinal plants, minerals and organic matter (Grover et al., 2002). A number of medicinal plants, traditionally used for over 1000 years named rasayana are present in herbal preparations of indian traditional health care systems (Speroni and Scatrtezzini, 2000). Despite the plant being referred to as 'nontoxic' this does not appear to be the case. While supplemental dosages appear to be safe from all tested toxicity a relatively small increase (3-4 times the recommended does) is known to cause genotoxic damage and may promote cancer formation whereas doses higher than that cause overt organ damage (mostly liver and kidneys). Beyond that, very reasonable supplemental dosages appear to be able to induce abortions in pregnant rats and thus supplementation is contraindicated (not advised) in pregnant women.

The water extracts of Moringa seeds, when injected into mice, have been noted to possess an acute $L_{50}$ of $446.5 \mathrm{mg} / \mathrm{kg}$ (Keter and Mutiso, 2011) and injections of the leaf water extracts have noted an $L_{50}$ of $1,585 \mathrm{mg} / \mathrm{kg}$ in mice (Awodele et al. 2012). There is a known LD $_{50}$ 
value with injections of the water extracts which is fairly low (relative to supplemental dosages). A water extract has failed to cause toxicity when orally administered up to this dose over 60 days (Awodele et al., 2012) although one study using the water extract at $3,000 \mathrm{mg} / \mathrm{kg}$ daily noted genotoxic potential in
PBMC (peripheral blood mononuclear cells) immune cells $(1,000 \mathrm{mg} / \mathrm{kg}$ confirmed safe) despite no damage to organs (Asare et al., 2012). This research investigated the effect of some doses of Moringa oleifera on the relative weight and histology of developing cerebrum of young wistar rats.

\section{MATERIALS AND METHODS}

Fifteen (15) young wistar rats of both sexes weighing 20-30g were used for this study. They were obtained and housed in standard cages under standard conditions. They were fed with feed pellets (grower mash). The Moringa oleifera leaf was obtained freshly from Ogbomosho North local government,Oyo State Nigeria. The leaf was identified by $\mathrm{Dr}$ (Mrs) Ogundola of Pure and applied Biology Department, Ladoke Akintola University of Technology Ogbomosho. The plant was air dried for 2 weeks, pulverized using mortar and pestle and was grinded into a fine powder. The aqueous extract of Moringa oleifera was prepared by soaking the powdered form in distilled water for about 24hrs then evaporated at about $55^{\circ} \mathrm{C}$. The extraction of Moringa oleifera was done at the Food Science and Engineering Department. The extract was then mixed with distilled water for administration. The extract measured $178 \mathrm{~g}$ before extraction and $150 \mathrm{~g}$ after extraction. After acclimatization period, the rats were weighed and divided into three groups comprising of 5 animals each. Group A rats (control group) were fed with pellet and equivalent volume of $0.25 \mathrm{ml}$ distilled water only. Group B rats were given $100 \mathrm{mg} /$ $\mathrm{kg} / \mathrm{bw}$ of aqueous extract of Moringa oleifera and also. Group C rats were given $200 \mathrm{mg} / \mathrm{kg} / \mathrm{bw}$ of aqueous extract of Moringa. The rats were weighed, the feed and water intake were also recorded daily. At the end of the experimental period (6 weeks), rats were weighed and sacrificed under ketamine (30 $\mathrm{mg} / \mathrm{kg}$ ) anaesthesia. The cerebrum was removed and fixed immediately in $10 \%$ neutral buffered formalin, for preservation. It was processed using paraffin wax embedding method. Sections of $5 \mu \mathrm{m}$ thickness were cut from the paraffin embedded tissues and stained with haematoxylin and eosin stain to demonstrate the general histoarchitecture of the Frontal cortex. Stained sections were viewed under a Leica DM750 microscope (Leica Microsystems, Heerbrugg, Switzerland) with digital camera attached (Leica ICC50) and digital photomicrographs were taken at various magnifications. One-way ANOVA was used to analyze data, followed by Student-NewmanKeuls (SNK) test for multiple comparisons. GraphPad Prism 5 (Version 5.03; Graphpad

Software Inc., San Diego, CA) was the statistical package used for data analysis. Statistically significant difference was set at $\mathrm{p}<0.05$.

\section{RESULT}

Statistical analysis of the results revealed that feed intake of the animals in group $B$ was significantly different $(p<0.05)$ compared to the control group from the 4th week of administration, while group $C$ animals feed intake was significantly different from group $A$ (control) throughout the six weeks of administration (Table 1 and Figure 1). There was no significant difference $(p<0.05)$ in the relative brain weight of animals in group $B$ and $\mathrm{C}$ when compared to the control (Figure 2). The ANOVA showed that there was no significant difference $(p<0.05)$ in the mean weight of animals in group $\mathrm{B}$ and $\mathrm{C}$ when compared to the control group (Figure 3). 
TABLE 1: Shows the feed intake of the effect of Moringa oleifera on the developing cerebrum of young wistar rats.

\begin{tabular}{|c|c|c|c|c|c|c|}
\hline & Week 1 & Week 2 & Week 3 & Week 4 & Week 5 & Week 6 \\
\hline $\begin{array}{l}\text { Group } 1 \\
\mathrm{~N}=5\end{array}$ & $\begin{array}{l}62.40 \pm \\
0.13\end{array}$ & $\begin{array}{l}80.40 \pm \\
0.13\end{array}$ & $\begin{array}{l}81.00 \pm \\
0.71\end{array}$ & $\begin{array}{l}102.8 \pm \\
0.06\end{array}$ & $\begin{array}{l}132.0 \pm \\
0.71\end{array}$ & $\begin{array}{l}123.6 \pm \\
0.11\end{array}$ \\
\hline $\begin{array}{l}\text { Group } 2 \\
\mathrm{~N}=5 \\
\text { Grp 1vs } 2 \\
\text { p-value }\end{array}$ & $\begin{array}{l}62.20 \pm \\
0.70 \\
0.7853\end{array}$ & $\begin{array}{l}61.60 \pm \\
0.06 \\
<0.0001^{*}\end{array}$ & $\begin{array}{l}83.00 \pm \\
1.00 \\
\\
0.1411\end{array}$ & $\begin{array}{l}106.8 \pm \\
0.14 \\
<0.0001^{*}\end{array}$ & $\begin{array}{l}137.4 \pm \\
0.14 \\
<0.0001^{*}\end{array}$ & $\begin{array}{l}157.0 \pm \\
0.89 \\
<0.0001^{*}\end{array}$ \\
\hline $\begin{array}{l}\text { Group } 3 \\
\mathrm{~N}=5 \\
\text { Grp 1vs } 3 \\
\mathrm{p}-\text {-value }\end{array}$ & $\begin{array}{l}59.00 \pm \\
0.32 \\
<0.0001^{*}\end{array}$ & $\begin{array}{l}77.00 \pm \\
0.71 \\
0.0015^{*}\end{array}$ & $\begin{array}{l}85.00 \pm \\
0.63 \\
0.0029 *\end{array}$ & $\begin{array}{l}106.0 \pm \\
0.63 \\
0.0010^{*}\end{array}$ & $\begin{array}{l}136.0 \pm 1.3 \\
0.0272 *\end{array}$ & $\begin{array}{l}164.4 \pm \\
0.14 \\
<0.0001^{*}\end{array}$ \\
\hline
\end{tabular}

Values are expressed as mean \pm sem, $A=$ control $B=100 \mathrm{mg} / \mathrm{kg} \mathrm{C}=200 \mathrm{mg} / \mathrm{kg}, \mathrm{p}<0.05$

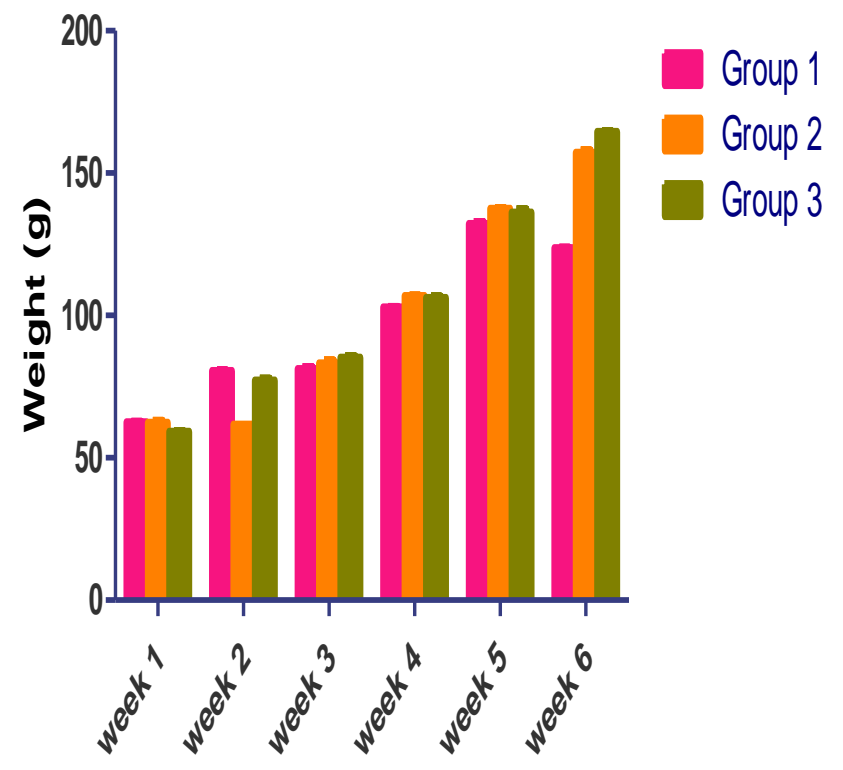

Figure 1: Shows the feed intake of the effect of Moringa oleifera on the developing cerebrum of young wistar rats. Values are expressed as mean \pm sem, $A=$ control $B=100 \mathrm{mg} / \mathrm{kg} \mathrm{C}=200 \mathrm{mg} / \mathrm{kg}, \mathrm{p}<0.05$

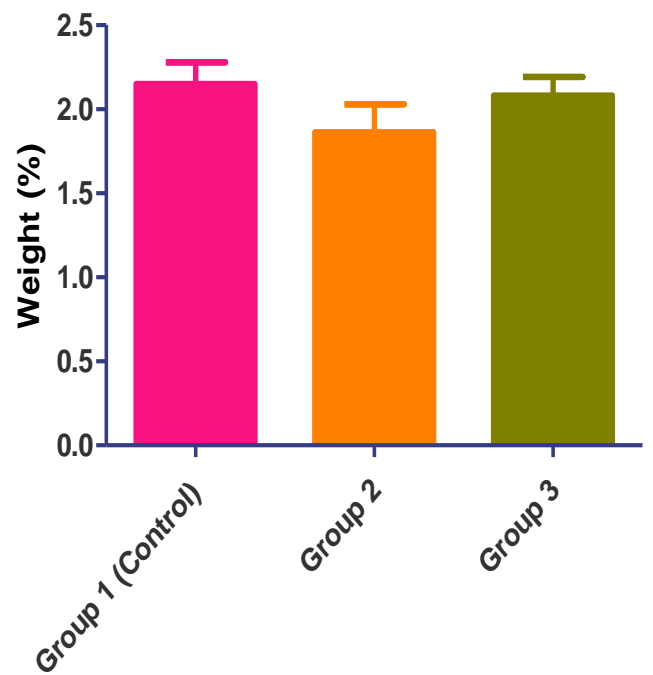

Figure 2: Showed the relative brain weight of the effect of Moringa oleifera on the developing cerebrum of young wistar rats. Values are expressed as mean \pm sem, $A=$ control $B=100 \mathrm{mg} / \mathrm{kg} \mathrm{C}=200 \mathrm{mg} / \mathrm{kg}, \mathrm{p}<0.05$ 


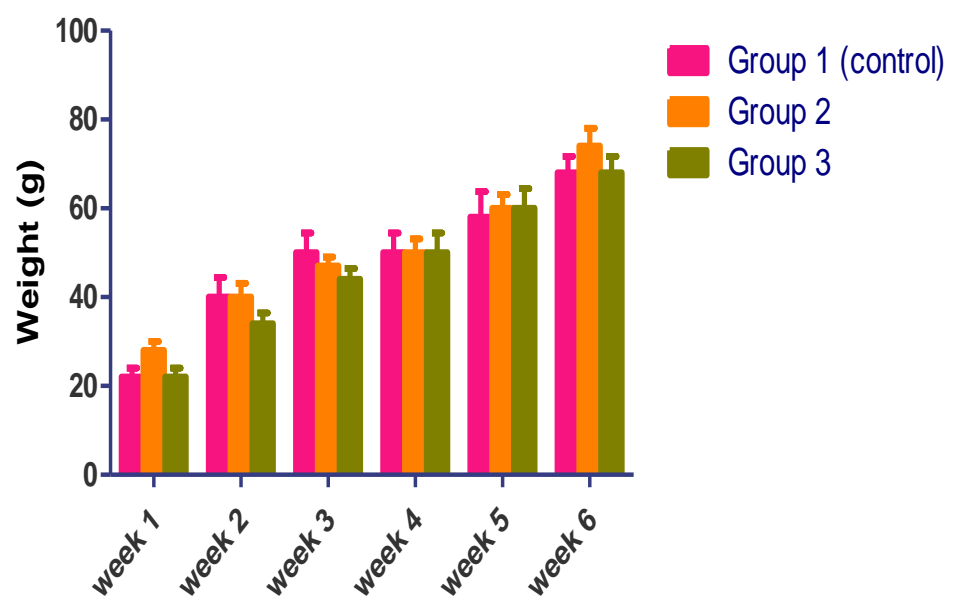

Figure 3: Showed the mean weight of the effect of Moringa oleifera on the developing cerebrum of young wistar rats. Values are expressed as mean \pm sem, $A=$ control $B=100 \mathrm{mg} / \mathrm{kg}$ $\mathrm{C}=200 \mathrm{mg} / \mathrm{kg}, \mathrm{p}<0.05$.

Histological findings

Normal histological features were seen in group A. In group B there was little distortion therefore, enlarged perivascular space and

scanty

oligodendrocytes. Scanty pyramidal neurons, pyknotic pyramidal neurons and oligodendrocytes appears normal were seen in group C (Figure 4).
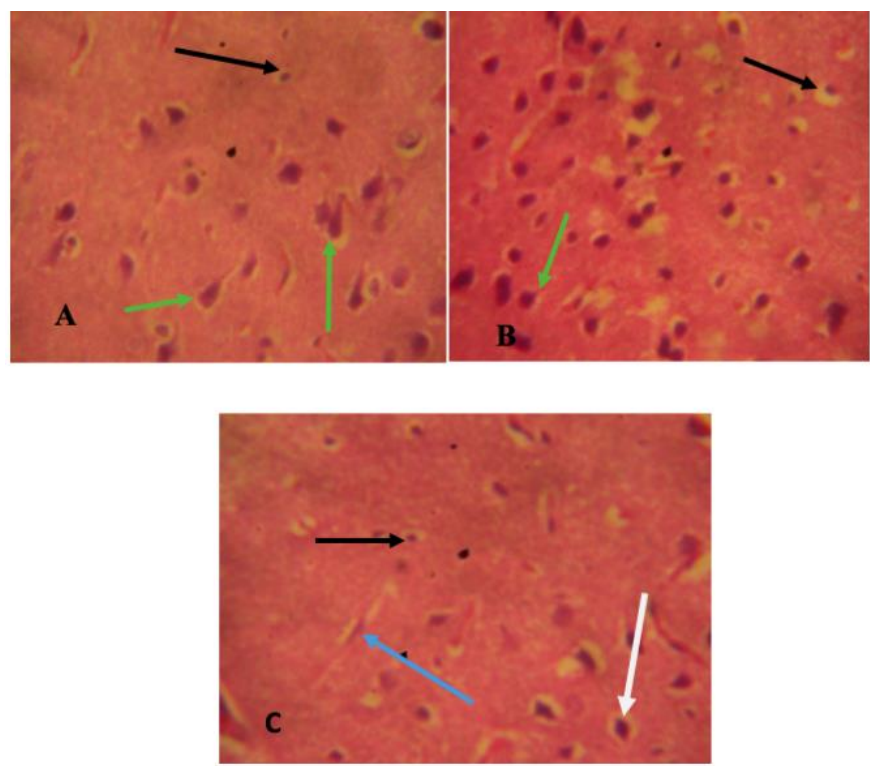

Figure 4: Showed the histology of prefrontal cortex of the effect of Moringa oleifera on the developing cerebrum of young wistar rats. $A=$ control $B=100 \mathrm{mg} / \mathrm{kg} C=200 \mathrm{mg} / \mathrm{kg}$, the evenly distributed pyramidal neurons (Green arrow), perivascular space and oligodendrocytes (black arrow), pyknotic pyramidal neurons (blue arrow), scanty pyramidal neurons (white arrow) $\cdot H \& E(X 400)$ 


\section{DISCUSSION}

This study was carried out to determine some of the effects of Moringa oleifera on the microarchitecture of the cerebrum of developing Wistar rats, average weight of the animals and on the relative brain weight of the animals.

Histological findings revealed that the control group notes normal evenly distributed pyramidal neurons, normal perivascular space and oligodendrocytes. All these are in conformity with the normal histology of the cerebrum which has been already reported (Nassi et al., 2015).

The photomicrograph of group B which received $100 \mathrm{mg} / \mathrm{kg}$ of the extract showed normal evenly distributed pyramidal neurons, enlarged perivascular space and scanty oligodendrocytes. This shows a slight distortion in the microarchitecture of the prefrontal cortex. It has been reported that despite the plant being referred to as 'nontoxic' this does not appear to be the case (Awodele et al., 2012). While supplemental dosages appear to be safe from all tested toxicity, a relatively small increase (3-4 times the recommended does) is known to cause genotoxic damage and also high doses causes overt organ damage (Awodele et al., 2012).

The photomicrograph of group $C$ which received $200 \mathrm{mg} / \mathrm{kg}$ of the extract showed scanty pyramidal neurons, pyknotic pyramidal neurons and oligodendrocytes appears normal. This also shows a slight distortion in the microarchitecture of the prefrontal cortex. It had been early shown that herbal extracts have the potential to produce adverse effect, especially when administered in toxic forms ( $\mathrm{Hu}$ et al., 2005). However, large amounts of these herbs may lead to toxic overload that may involve complications, some of a serious nature and should be used with caution (Asomugha et al., 2015)

In the present study feed intake of the rats in group B was significantly increased when compared with control group from the 4th week of administration, while group $\mathrm{C}$ animals feed intake was also significantly increased than control throughout the six weeks of administration. This was in accordance with the study done by Ghebreselassie et al (Ghebreselassie et al., 2011). He reported that Mice treated with $900 \mathrm{mg} / \mathrm{kg}$ of the extract were increased in body weight when compared with the controls (Ghebreselassie et al., 2011; Asomugha et al., 2015). This implies that moringa oleifera increases feed intake which resulted in significant increased in weight of animals in group $B$ and $C$ when compared with the control group.

In conclusion, the results obtained from this present study suggested that excessive and high doses of consumption of Moringa oleifera caused some slight distortions in the histoarchitecture of the frontal cortex of developing wistar rats

\section{REFERENCES}

1. Asare GA, Bugyei K, Sittie A, Yahaya ES, Gyan B, Adjei S, Addo P, Wiredu EK, Adjei DN, Nyarko AK. 2012. Genotoxicity, Cytotoxicity and Toxicological Evaluation of Whole Plant Extracts of the medicinal plant Phyllanthus niruri (Phyllanthaceae). Genetic and Molecular Research 11(1): 100111

2. Asomugha AL, Ezejindu DN, Asomugha RN, Anyabolu AE, Ojukwu PC. 2015. Evaluation of Toxicity Effect of Graded Doses of Moringa oleifera Leaf Extract on Blood Indices Using 20 Adult Wistar Rats. International Journal of Biomedical and Advance Research 6(02): 98-102

3. Awodele O, Adekunle I O, Odoma S, da Silva JAT, Osunkalu VO. 2012. Toxicological evaluation of the aqueous leaf extract of Moringa oleifera Lam. (Moringaceae). Journal of Ethnopharmacology 139: 330- 336

4. Ghebreselassie D, Yalemtsehay M, Girmai G. 2011. The effects of Moringa stenopetala on blood parameters and histopathology of liver and kidney in mice. Ethiop J Health Dev. 25 (1):51-57. 
5. Grover JK, Yadav S, Vats V. 2002. Medicinal Plants of India with Anti- diabetic Potential. Journal of Ethnopharmacology 81: 81- 100

6. Hu Z, Yang X, Ho PCL, Chan SY, Heng PWS, Chan E, Duan W, Koh HL, Zhou S. 2005. Herbdrug interactions: A literature review. Drugs 65: 1239-1282.

7. Keter LK, Mutiso PC. 2011. Ethnobotanical Studies of Medicinal Plants used by Traditional Health practitioners in the Management of Diabetics in lower Eastern Province, Kenya. Journal of Ethnopharmacology 139: 74- 80

8. Nassi J], Cepko CL, Born RT, Beier KT. 2015. Neuroanatomy. Front. Neuroanat. 9:80.

9. Osman HM, Shayoub ME, Babiker EM, Faiza AO, Munzir MEA, Bashier O, Ali ME, Taha KK. 2015. Assessment of acute toxicity and LD50 of Moringa oleifera ethanolic leave extract in albino rats and rabbits. Journal of Medical and Biological Science Research 1(4): 38-43,

10. Speroni E, Scartetzzini P. 2000. Review on some plants of Indian traditional medicine with antioxidant activity. Journal of Ethnopharmacology 71(1-2): 23- 43 